\begin{tabular}{|l|l|l|}
\hline \multicolumn{2}{|c|}{ PublisherInfo } \\
\hline \hline PublisherName & $:$ & BioMed Central \\
\hline \hline PublisherLocation & $:$ & London \\
\hline \hline PublisherImprintName & $:$ & BioMed Central \\
\hline \hline
\end{tabular}

\title{
Watch out for the neighbors
}

\begin{tabular}{|l|l|l||}
\hline \multicolumn{2}{|c|}{ ArticleInfo } \\
\hline \hline ArticleID & $:$ & 3794 \\
\hline \hline ArticleDOI & $:$ & $10.1186 /$ gb-spotlight-20001010-02 \\
\hline \hline ArticleCitationID & $:$ & spotlight-20001010-02 \\
\hline \hline ArticleSequenceNumber & $:$ & 231 \\
\hline \hline ArticleCategory & $:$ & Research news \\
\hline ArticleFirstPage & $:$ & 1 \\
\hline \hline ArticleLastPage & $:$ & 2 \\
\hline \hline & & RegistrationDate : 2000-10-10 \\
ArticleHistory & $:$ & OnlineDate $\quad 2000-10-10$ \\
\hline \hline ArticleCopyright & $:$ & BioMed Central Ltd2000 \\
\hline \hline ArticleGrants & $:$ & \\
\hline \hline ArticleContext & $:$ & 130591111 \\
\hline \hline
\end{tabular}




\section{William Wells}

Email: wells@biotext.com

Radiation induces DNA breaks, leading to chromosomal rearrangements. But do the breaks come first, followed by a wandering through the nucleus to find a suitable partner for the free DNA end? Or is the partner already nearby at the time of the break? In the 6 October Science, Nikiforova et al. provide evidence for the latter theory (Science 2000, 290:138-141). They look at papillary thyroid cancer, in which a radiation-induced inversion often fuses the genes for $\mathrm{H} 4$ and the RET receptor tyrosine kinase. In normal thyroid cells the genetic distance between these two genes is $30 \mathrm{Mb}$, but Nikiforova et al. find that in $35 \%$ of thyroid cells the genes are physically very close together. The restriction of the RET-H4 rearrangement to thyroid cancers (and not lymphomas or breast cancers) may have two different explanations. Lymphocytes, at least in mice, are not transformed by activated RET, and mammary epithelial cells do not show association of the RET and $\mathrm{H} 4$ genes.

\section{References}

1. Science magazine, [http://www.sciencemag.org/]

2. Oncogenic rearrangements of the RET proto-oncogene in papillary thyroid carcinomas from children exposed to the Chernobyl nuclear accident. 